\title{
SURFACE INTEGRITY EVALUATION OF TURNING WITH AUTO-ROTATING TOOL
}

\author{
Jozef Struharnansky', Marek Kordik', Anton Martikan', \\ Dana Stancekova', Jozef Pilc' ${ }^{1}$, Karol Vasilko ${ }^{2}$
}

1 Faculty of Mechanical Engineering, University of Žilina, Univerzitna 1, 01026 Žilina, Slovakia, e-mail: jozef.struharnasky@fstroj.uniza.sk, marek.kordik@fstroj.uniza.sk, anton.martikan@fstroj.uniza.sk, dana. stancekova@fstroj.uniza.sk, jozef.pilc@fstroj.uniza.sk

2 Faculty of Manufacturing Technologies, Technická Univerzita v Košiciach so sídlom v Prešove, Bayerova 1, 08001 Presov, Slovakia, e-mail: karol.vasilko@tuke.sk

Received: 2016.06.04

Accepted: 2016.07.05 Published: 2016.09.01

\begin{abstract}
The technical practice requirements comes to have increased demands on higher productivity, speed and quality of the machining process of various materials. Hard to machine materials, whose machining led to the development of turning with rotating cutting edge are not an exception. The machining process of auto-rotating tool is more complicated than the conventional process of turning, especially for the process of reshaping cutting layers into chips. There is a significant load in the system, that may affect the life of the cutting edge of the tool as well as the whole system and also in the final extent of the qualitative parameters of the workpiece (product / product). The article specifies the knowledge and findings of measurement in machining material $100 \mathrm{Cr} 6$ with an auto-rotating tool. The measurements were conducted to evaluate the integrity of the surface (roughness) of the workpiece to the impacts of cutting conditions, in particular the feed and the cutting edge inclination. It also analyzes the presence (size, character, action) of residual stresses concentrated in the surface layers of the workpiece by changing the cutting conditions.
\end{abstract}

Keywords: residual stress, turning, roughness, autorotation-tool, surface.

\section{INTRODUCTION}

In relation to the cause of rotary motion of the tool in the machining process, the authors divided these tools into two basic groups:

- forced rotation tools,

- auto-rotating tools $[1,2]$.

Tools with forced rotation has the motion enabled by a standalone drive. The tools of another group are forced to rotary motion by friction between contact surfaces of the tool and workpiece. Both of the tool motion principles can be used in:

- turning (as turning tools),

- planing (as planing tools),

- milling (as milling tools) $[1,3,4]$.

\section{MEASUREMENT OF RESIDUAL STRESS}

From the theory of elasticity the relationship between residual stress $(\sigma)$ and strain $(\varepsilon)$ on the sample surface under plane stress is given by the Bragg equation, $\lambda=2 \mathrm{~d} \sin \theta$, relating incident $X$-ray wavelength $(\lambda)$, lattice inter-planar spacing (d) and diffraction angle $(\theta)$ (Fig. 1).

The direction of maximum residual stress that can be tensile or compressive, is assumed to occur in the cutting or grinding direction during most machining operations $[5,6,7]$. 


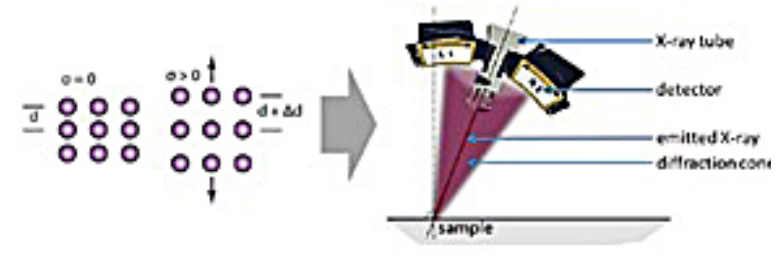

Fig. 1. Principle of measuring of residual stress by X-ray diffractometry based on Brag's Law [5]

\section{CONDITION OF THE EXPERIMENT}

The experiment was performed on lathe SUI 40. Cutting parameters set was based on previous experiment, as constant revolutions and depth of cut: $n=600 \mathrm{~min}^{-1}, a_{p}=0.5 \mathrm{~mm}$, angle of cutting edge $\kappa_{s}=\left(30^{\circ}, 45^{\circ}, 50^{\circ}\right)$, feed $f$ $=(0.3 ; 0.45 ; 0.7 ; 0.9) \mathrm{mm}$. Workpiece diameter $d=50 \mathrm{~mm}$. Based on theoretical calculation of roughnes $[1,8,9]$, we continued on roughness parameters verification. Subsequently, after performed experiments we detected the residual stresses of machined surface by unconventional

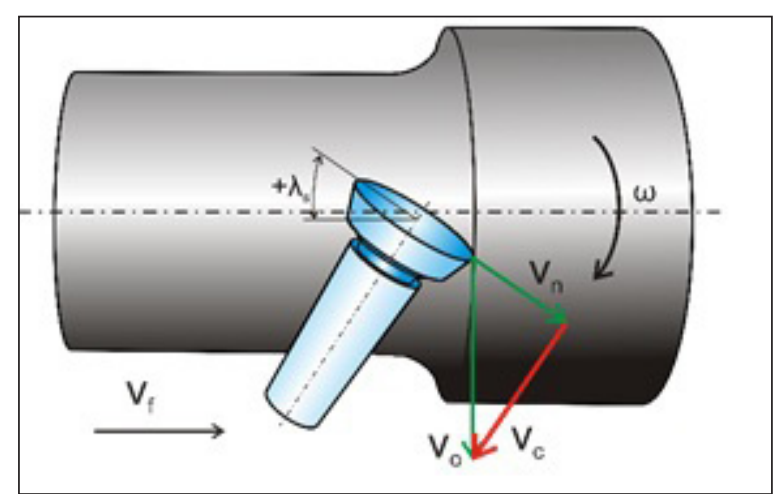

Fig. 2. Tool position relative to workpiece, negative angle $\kappa_{\mathrm{s}}[13]$

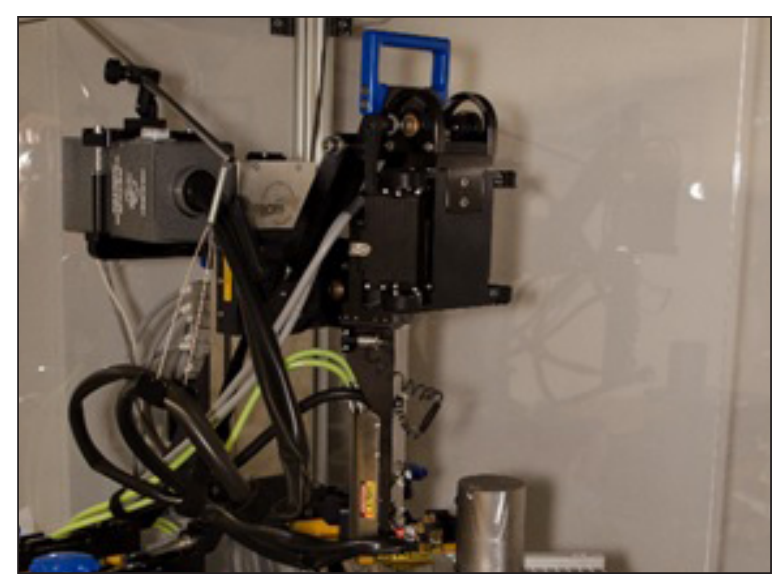

Fig. 3. Process of residual stress measurement with XRD diffractionmeter tool with a circular rotating disc. Roughness measurement was set in accordance with DIN EN ISO 4288: 1988. Position of the tool to the workpiece has a negative angle on the cutting edge as shown in Figure $2[1,10,11,12]$.

Next, the results were made using a Mitutoyo SJ 400, residual stresses in the surface layer was measured by X-ray diffractometer PROTO iXRD which is shown in Figure 3. The depth of the penetrating X-ray beam is $8-12$ microns, depending on the voltage on the lamp. Machined material was bearing steel $100 \mathrm{Cr} 6,[14,15,16]$, the microstructure is shown in Figure 4.

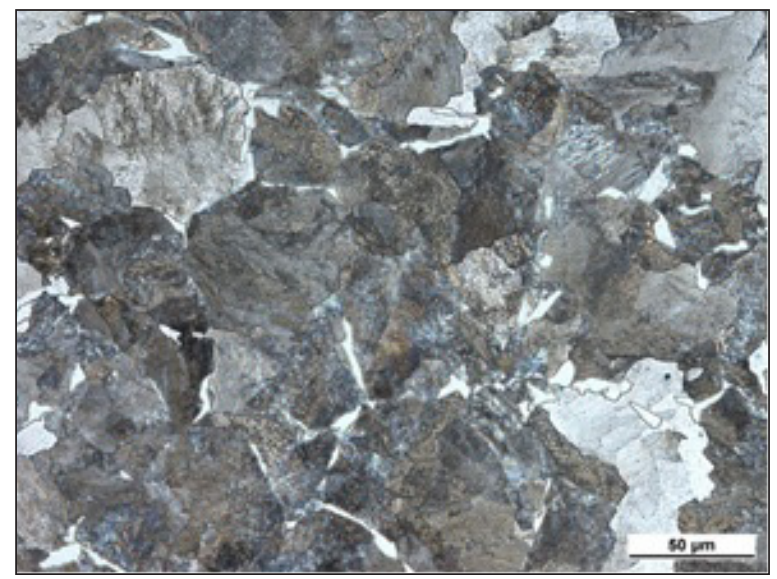

Fig. 4. Microstructure of bearing steel 100Cr6

\section{RESULTS OF EXPERIMENTS}

Record of roughness measurement under cutting conditions $K_{\mathrm{s}}=30^{\circ}$ and feed $\mathrm{f}=0.45 \mathrm{~mm}$ is shown in Figure $5 \mathrm{a}$ and cutting conditions $\kappa_{\mathrm{s}}=$ $50^{\circ}$ and feed $\mathrm{f}=0.9 \mathrm{~mm}$ is shown in Figure $5 \mathrm{~b}$.

For selected parameters the three-dimensional roughness diagrams were constructed that are shown in Figure 6. The selected numerical values of these measurements are shown in Table 1. The surface roughness is calculated as the arithmetic mean of the three measurements. The advantage of these diagrams is that they show the overall progress of roughness depending on the inclination of the cutting edge $\kappa_{\mathrm{s}}$ and feed $\mathrm{f}$.

Table 1. Surface roughness parameters

\begin{tabular}{|c|c|c|c|c|c|c|}
\hline \multirow{2}{*}{$\begin{array}{c}\text { Feed } \mathrm{f} \\
{[\mathrm{mm}]}\end{array}$} & \multicolumn{2}{|c|}{$\lambda_{\mathrm{s}}=30^{\circ}$} & \multicolumn{2}{c|}{$\lambda_{\mathrm{s}}=45^{\circ}$} & \multicolumn{2}{c|}{$\lambda_{\mathrm{s}}=50^{\circ}$} \\
\cline { 2 - 7 } & $\mathrm{f}=0.45$ & $\mathrm{f}=0.9$ & $\mathrm{f}=0.45$ & $\mathrm{f}=0.9$ & $\mathrm{f}=0.45$ & $\mathrm{f}=0.9$ \\
\hline $\begin{array}{c}\mathrm{Ra} \\
{[\mu \mathrm{m}]}\end{array}$ & 5.50 & 4.06 & 2.10 & 2.31 & 2.34 & 6.59 \\
\hline $\begin{array}{c}\mathrm{Rz} \\
{[\mu \mathrm{m}]}\end{array}$ & 30.30 & 20.87 & 12.00 & 13.27 & 14.83 & 20.40 \\
\hline
\end{tabular}




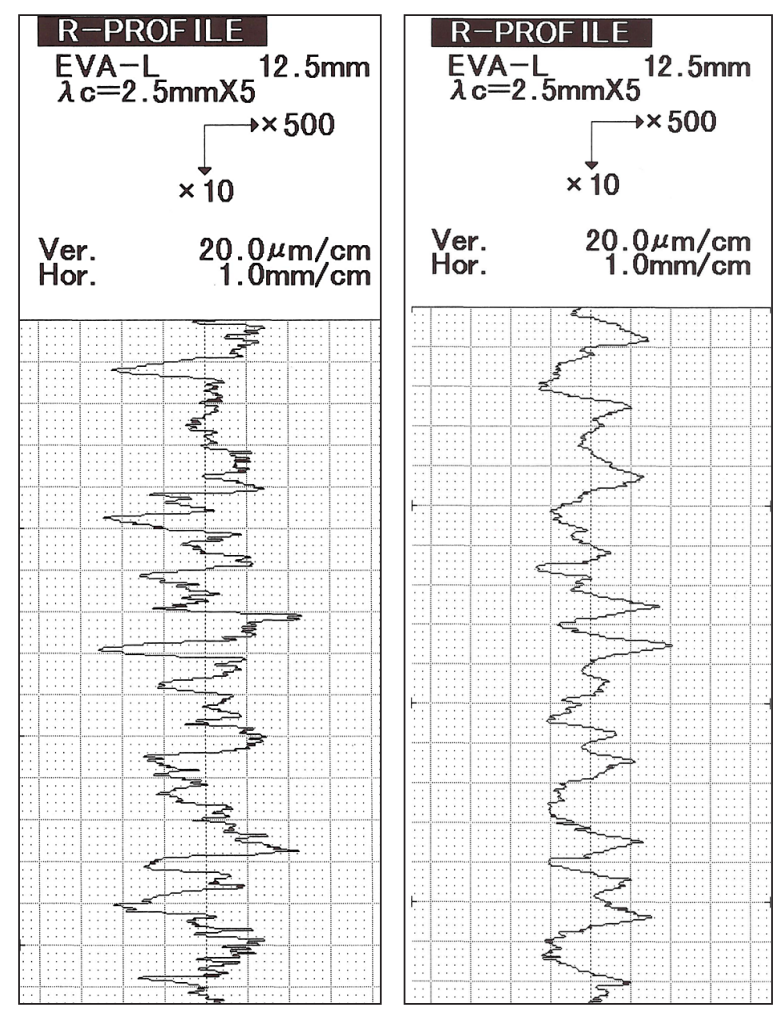

Fig. 5. Roughness graphs of surface machined with rotary tool: $\Lambda_{\mathrm{s}}=30^{\circ}, \mathrm{f}=0.45 \mathrm{~mm}$ (left) and $\kappa_{\mathrm{s}}=50^{\circ}, \mathrm{f}=0.9 \mathrm{~mm}$ (right)

Chosen parameters of the average values of residual stresses were processed into Table 2. The mean value of 36 measurements were carried out in $10^{\circ}$ by rotating the sample as shown in Figure 7.

By residual stress measuring several parameters were monitored such as normal residual stress, shear stress and FWHM parameter. Tension $\sigma$ is the normal stress relative to sample surface. FWHM is fullwidth at half maximum and determines the width of Gaussian distribution.

For the selected cutting conditions the graph of residual stresses was made, depending on the cutting conditions and angular rotation. The graph of residual stresses is shown in Figure 8 and 9.
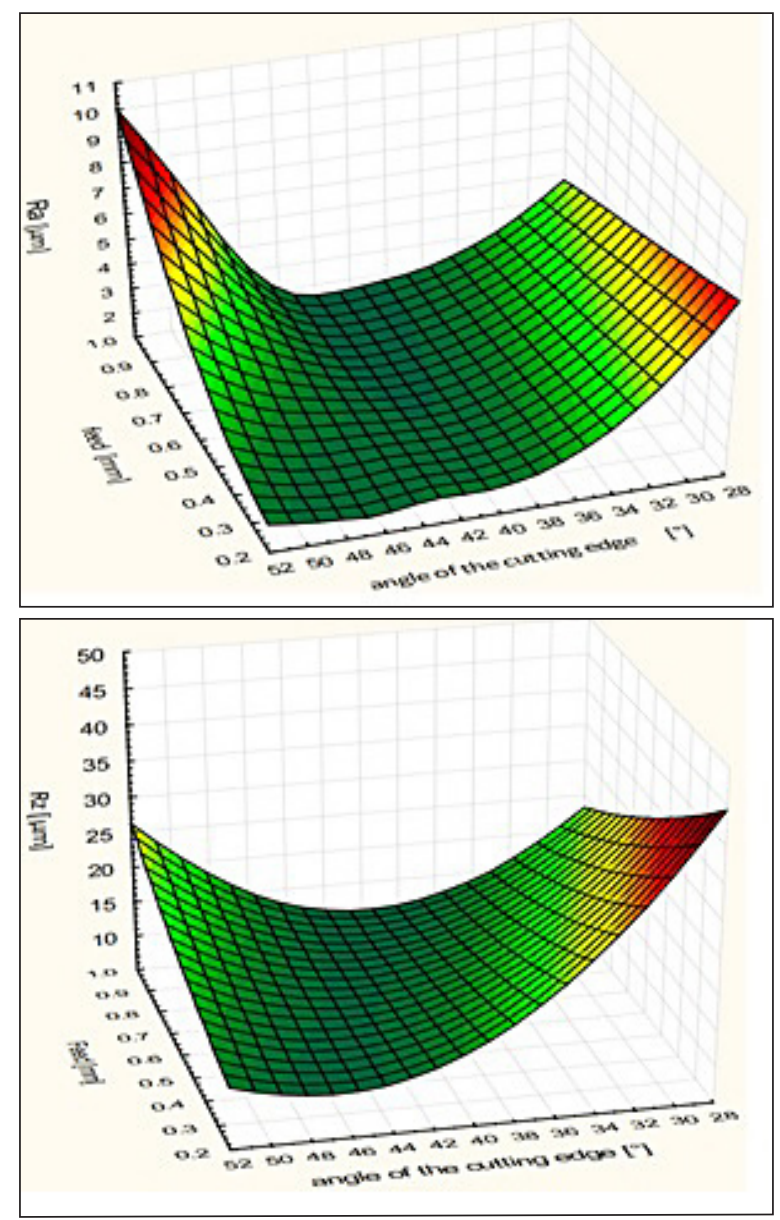

Fig. 6. Roughness parameter Ra in turning with autorotary tool (above) and roughness parameter $\mathrm{Rz}$ in turning with auto-rotary tool (below)

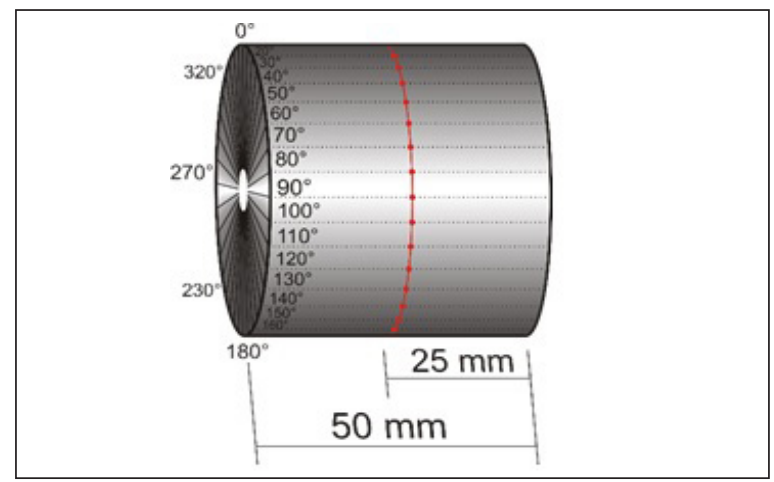

Fig. 7. Position of measured points for X-ray diffraction

Table 2. Residual stress values in turning with rotary tool

\begin{tabular}{|c|c|c|c|c|c|c|c|c|c|}
\hline $\begin{array}{c}\text { Depth of } \\
\text { cutt } a_{p}[\mathrm{~mm}]\end{array}$ & $\begin{array}{l}\text { Feed f } \\
{[\mathrm{mm}]}\end{array}$ & $\begin{array}{c}\text { Angle of the cutting } \\
\text { edge }\left[^{\circ}\right]\end{array}$ & \multicolumn{3}{|c|}{ Residual stress $\sigma$ [MPa] } & \multicolumn{3}{|c|}{ Shear stress $\mathrm{T}[\mathrm{MPa}]$} & FWHM $\left[^{\circ}\right]$ \\
\hline \multirow{6}{*}{0.5} & 0.45 & \multirow{2}{*}{30} & 127.14 & \pm & 13.33 & -126.10 & \pm & 6.67 & 2.79 \\
\hline & 0.9 & & 125.25 & \pm & 14.19 & -125.68 & \pm & 14.19 & 2.81 \\
\hline & 0.45 & \multirow{2}{*}{45} & 189.73 & \pm & 12.84 & -118.96 & \pm & 6.71 & 2.80 \\
\hline & 0.9 & & 247.98 & \pm & 14.32 & 20.14 & \pm & 7.16 & 2.83 \\
\hline & 0.45 & \multirow{2}{*}{50} & 228.26 & \pm & 11.14 & 12.70 & \pm & 5.59 & 2.76 \\
\hline & 0.9 & & 564.35 & \pm & 43.48 & -146.79 & \pm & 21.76 & 2.73 \\
\hline
\end{tabular}




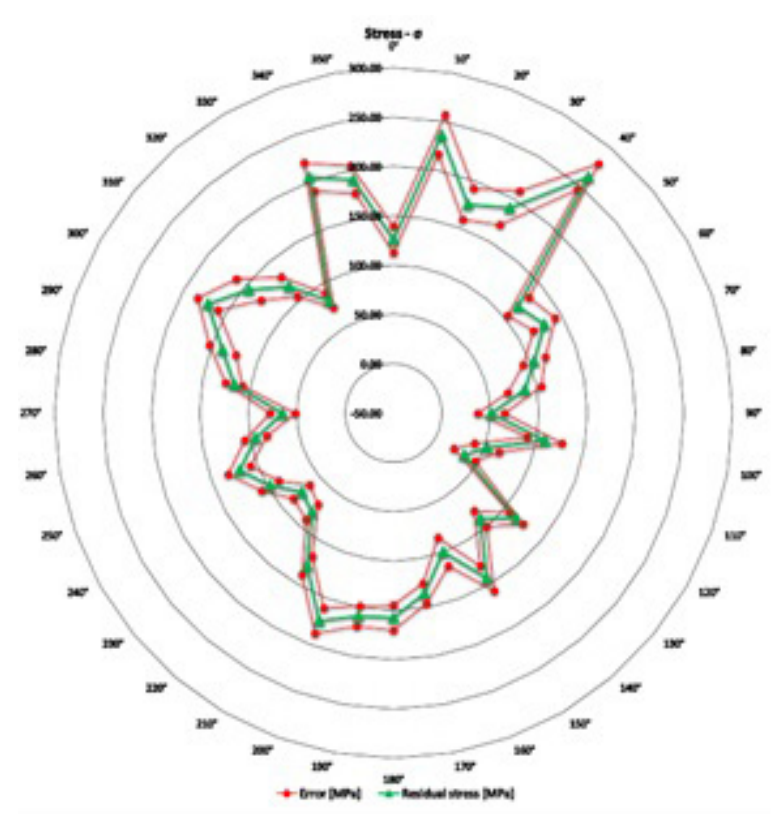

Fig. 8. Residual stress graph with cutting parameters $\Lambda_{\mathrm{s}}=30^{\circ}, \mathrm{f}=0,45 \mathrm{~mm}$

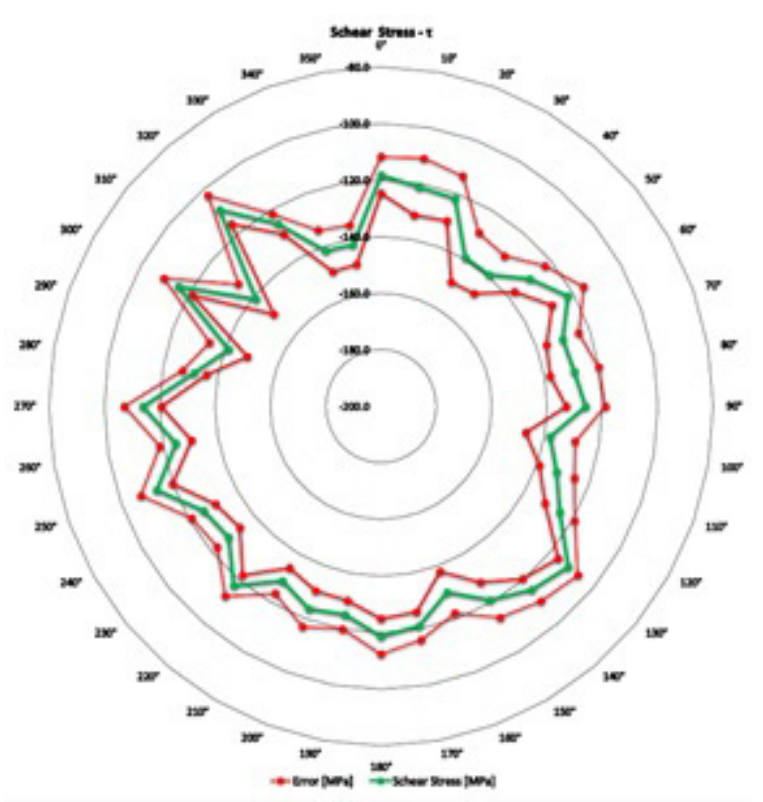

Fig. 9. Shear stress graph with cutting parameters $\Lambda_{\mathrm{s}}=30^{\circ}, \mathrm{f}=0,45 \mathrm{~mm}$

\section{CONCLUSIONS}

From the experiment results, the lowest values of the roughness parameters $\mathrm{Ra}, \mathrm{Rz}$ are achieved with an angle of inclination $\kappa_{s}=45^{\circ}$. Feed rate $\mathrm{F}$ does not have such a significant impact, which in the feed $\mathrm{f}=0.45 \mathrm{~mm}$, the value of $\mathrm{Ra}=2.1 \mu \mathrm{m}$ and $\mathrm{Rz}=12 \mu \mathrm{m}$. When feed $\mathrm{f}=0.9 \mathrm{~mm}$, the value of $\mathrm{Ra}=2.31 \mu \mathrm{m}$ and $\mathrm{Rz}=13.27 \mu \mathrm{m}$. The worst results of surface quality were with $K \mathrm{~s}=50^{\circ}$ and feed $\mathrm{f}$

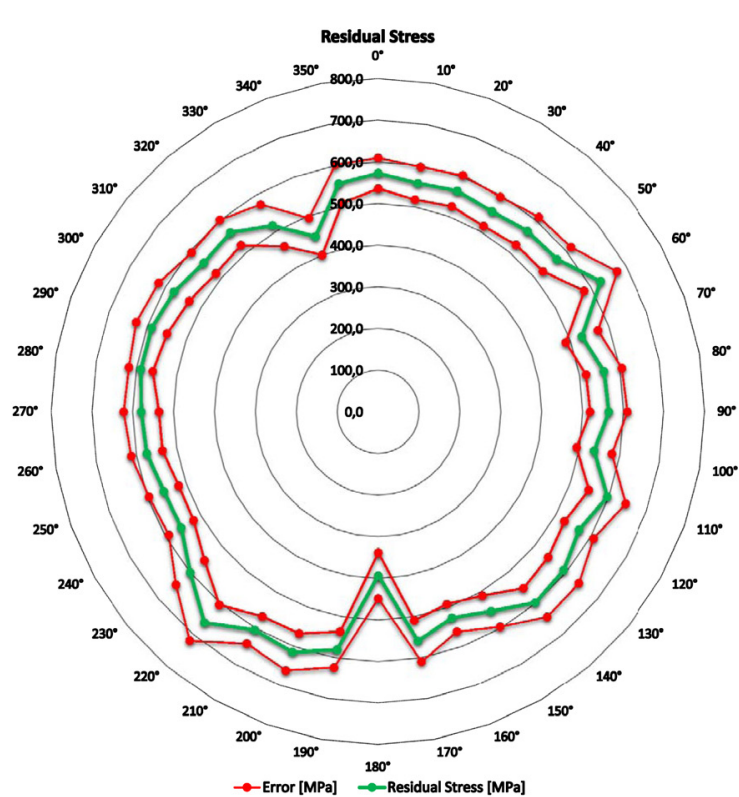

Fig. 10. Residual stress graph with cutting parameters $\Lambda_{\mathrm{s}}=50^{\circ}, \mathrm{f}=0,9 \mathrm{~mm}$

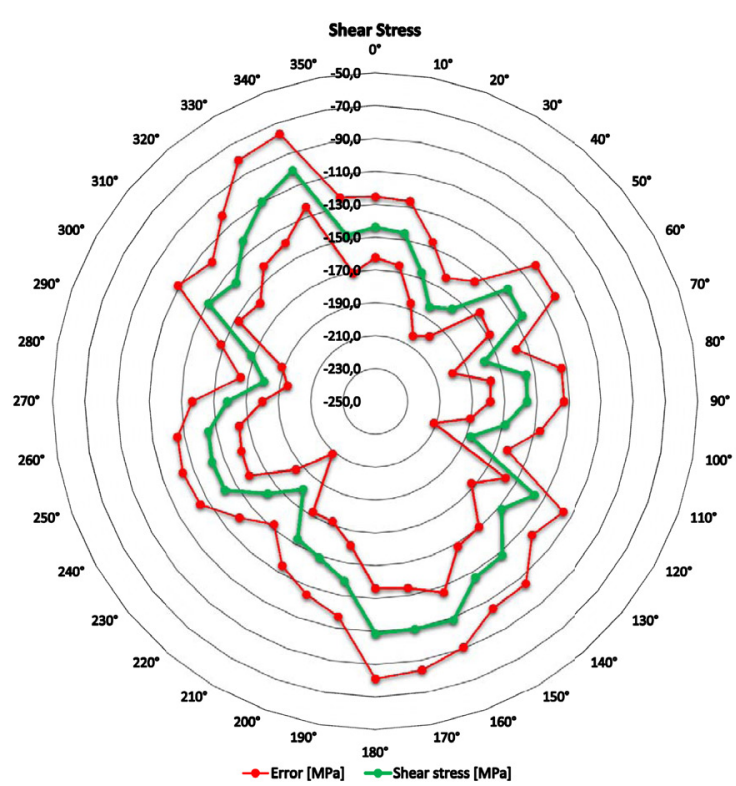

Fig. 11 Shear stress graph with cutting parameters $K \mathrm{~s}$ $=50^{\circ}, \mathrm{f}=0,9 \mathrm{~mm}$

$=0.9 \mathrm{~mm}$ where the Ra parameter had the value $6.59 \mu \mathrm{m}$. Rz for evaluation parameter was the worst quality achieved at $K \mathrm{~s}=30^{\circ}$, and feed $\mathrm{f}=$ $0.45 \mathrm{~mm}$, where the measured value was $30.3 \mu \mathrm{m}$.

In the evaluation of residual stress the best results were achieved when $K \mathrm{~s}=30^{\circ}$. Feed rate at the cutting edge ange has no significant impact on the size of the introduced stress into the material. Stress magnitude was around $125 \mathrm{MPa}$. All measurements of residual stresses using auto-rotary 
tools should have tensile character (determined by "+" sign), indicating the possible formation of cracks in the surface layers. Compared to the forged outer bearing ring, the compression stress in turning in component predispose a longer life [4]. With the increasing inclination of the cutting edge increases the impact of displacement on the size of residual stresses. Tested at maximum slope $K \mathrm{~s}=50^{\circ}$, the value stresses at the feed $\mathrm{f}=$ $0.45 \mathrm{~mm} \mathrm{228MPa}$ and at a feed $\mathrm{f}=0.9 \mathrm{~mm}$ was worth more than 2 times higher $\sigma=564 \mathrm{MPa}$.

The treatments of the material does not affect the FWHM parameter, because this parameter reflects the granular structure of the material.

\section{REFERENCES}

1. Vasilko K., Pilc J.: Tools and Technology for highly productive Wood Materials. Manufac-turing Engineering, 10(3), 2011, 8-13.

2. Stancekova D., Kurnava T., Sajgalik M., Naprstkova N., Struharnansky J., Ščotka, P.: Iden-tification of machinability of ceramic materials by turning. Manufacturing Technology, 14(1), 2014, 91-97.

3. Sapietová, A., Gajdoš, L., Dekýš, V., Sapieta, M.: Analysis of the influence of input func-tion contact Parameters of the impact force Process in the MSC. ADAMS. Advances in In-telligent Systems and Computing, 393(1), 2016, 243-253.

4. Sadílek M., Kratochvíl J., Petrů J.,Cep R., Zlámal T., Stančeková D.: Cutting tool wear mon-itoring with the use of impedance layers. Tehnicki Vjesnik, 21(3), 2014, 639-644.

5. Czan A., Martikan A., Holubjak J., Struharnansky J.: Identification of stress and structure properties in surface and subsurface layers of nuclear reactor austenitic steel. Manufactur-ing Technology, 14(3), 2014, 276-281.

6. Novotný J. Cais J., Náprstková N.: Analysis of aluminium alloys AlSi7Mg0.3 and AlMg3 by means of X-Ray diffraction, Manufacturing Technology,
14(3), 2014, 392-397.

7. Krolczyk G.M., Niesłony P., Legutko S.: Determination of tool life and research wear dur-ing duplex stainless steel turning. Archives of Civil and Mechanical Engineering, 15(2), 2015, 347-354.

8. Cubonova N., Kuric I.: Data structures implementation of the protocol STEP-NC at CNC machines programming. Komunikacie, Vol. 16, Iss. 3A, 2014, 176-183.

9. Bas G., Stoev L. Durakbasa N.M.: Assessment of the production quality in machining by integrating a system of high precision measurement. Energy Procedia, Vol. 100, Iss. C, 2015, 1616-1624.

10. Rudawska, A.: Influence of the thickness of joined elements on lap length of aluminium alloy sheet bonded joints. Advances in Science and Technology Research Journal, 9(27), 2015, 35-44.

11. Müller M., Chotěborský R., Valášek P., Hloch. S.: Unusual possibility of wear resistance increase research in the sphere of soil cultivation. Tehnicki Vjesnik-Technical Gazette, 20(4), 2013, 641-646.

12. Litvaj, I., Poniščiaková, O., Stančeková, D., Drbúl, M.: Knowledge processes and their im-plementation in small transport companies. In: Transport Means - Proceedings of the Inter-national Conference, 2013, 153-156.

13. Pilc, J.-Mičietová, A.: Obrábanie kovov autorotujúcimi nástrojmi. Žilina : EDIS, 2003. pp. 106.

14. Kordik, M., Struharnansky, J., Martikan, A., Stancekova, D., Kusmierzak, S., Martincek, J.: Insertcoating Influence on Residual Stress of Turned Outer Bearings. J. Manufacturing Technology, 16(1), 2016, 136-140.

15. Fulemová J., Řehoř, J.: Influence of form Factor of the Cutting Edge on Tool Life during Finishing Milling. In Procedia Engineering. Vídeň: Elsevier Ltd, 2015. 682-688.

16. Sadilek M., Fojtík F., Sadílková Z., Kolařík K., Petrů J.: A Study of Effects of Changing the Position of the Tool Axis to the Machined Surface, Transaction of FAMENA, 39(2), Zagreb 2015, 33-46. 